doi: 10.11567/met.31.1.5

\section{Međunarodna znanstvena konferencija »Migracije i etničnost na početku 21. stoljeća» - povodom 30 godina izlaženja časopisa Migracijske i etničke teme (1985. - 2015.)}

Zagreb, 26. veljače 2015.

Trideset godina izlaženja znanstvenog časopisa Migracijske $i$ etničke teme obilježeno je u Zagrebu 26. veljače 2015. međunarodnom znanstvenom konferencijom »Migracije i etničnost na početku 21. stoljeća «. Konferenciju je organizirao Institut za migracije i narodnosti, izdavač časopisa, s ciljem da se kroz izlaganja i rasprave istraživača različitih znanstvenih profila objasne pristupi istraživanju osnovnih tema predstavljenih u radovima časopisa, analiziraju različiti aspekti etničnosti i migracija te njihova povezanost, ispitaju učinci na grupnu $i$ individualnu identifikaciju te razmotre demografske promjene koje su rezultat migracijskih procesa ili odražavaju općenito kompleksne etničke odnose, a poglavito one na prostorima jugoistočne Europe (Knjiga sažeta$k a$, str. 7).

Nakon pozdravnih riječi glavna urednica Sanja Klempić Bogadi ukratko je izložila povijest časopisa osvrćući se na rad prethodnih urednika te pružajući uvid u osnovne bibliometrijske podatke o časopisu. Posebno je upozorila na okolnosti otežanog financiranja s kojim se susreću brojni znanstveni časopisi u Hrvatskoj. Na otvaranju konferencije uvodne i pozdravne govore održali su i Emil Heršak, bivši glavni urednik časopisa, te
Milan Mesić, utemeljitelj i prvi glavni urednik časopisa.

Konferencija je zbog velikog interesa sudionika, ponajprije iz Hrvatske, ali i iz Bosne i Hercegovine, Slovenije i Srbije, planirana kao niz paralelnih sesija kojima prethodi plenarni dio. Uz plenarnu sesiju održano je još sedam sesija koje su okupile izlaganja tematski grupirana pod nazivima: $M i-$ gracijska politika, državljanstvo i međunarodna mobilnost, Tržište rada, razvoj i migracije, Unutrašnje migracije: uzroci i posljedice, Imigracijski procesi i identitet, Nacionalne manjine: status i prava; Etničnost $i$ fertilitet te Multietničnost $i$ identitet. Konferencija je okupila više od šezdeset izlagača, a povremeno je s ostalim uzvanicima na izlaganjima bilo prisutno i više od sto sudionika.

Plenarna sesija okupila je neke od danas vodećih znanstvenika u području migracija i etničnosti. Vjeran Katunarić (Odjel za sociologiju, Sveučilište u Zadru) analizirao je povezanost migracija i katastrofa $s$ kritičko-hermeneutičke pozicije, Milan Mesić (Odjel za sociologiju, Filozofski fakultet Sveučilišta u Zagrebu) i Drago Župarić-Iljić (Institut za migracije i narodnosti) u svom su se radu bavili suvremenim tipom okolišnih migracija čiji su direktni povod promjene u okolišu. Saša Božić s Odjela za sociologiju Sveučilišta u Zadru razmatrao je suvremene migracije u odnosu na postavke metodološkoga nacionalizma i metodološkoga kozmopolitizma, a Ivo Nejašmić (Učiteljski fakultet Sveučilišta u Zagrebu) predstavio je demografske posljedice iseljavanja iz Hrvatske u posljednjih sto godina. Emil Heršak (Katedra za antropologiju Filozofskog fakulteta Sveučilišta 
u Zagrebu) u suautorstvu s Edinom Muftićem izložio je povijesno-filozofski pregled definiranja identiteta i pristupe identitetu. Izlaganje Foriana Biebera sa Sveučilišta u Grazu, posljednje u plenarnoj sesiji, bilo je usmjereno na propitivanje kategorija identiteta $\mathrm{u}$ postjugoslavenskim popisima stanovništva.

Prva sesija Migracijska politika, državljanstvo i međunarodna mobilnost sastojala se od pet izlaganja usmjerenih na analizu imigranata u kontekstu europske imigracijske politike i nacionalnih imigracijskih politika (Nella Popović) usporedbom politika državljanstva u Hrvatskoj devedesetih godina 20. stoljeća i danas (Dražen Hoffman) te medijskom diskursnom konstrukcijom imigrantske zajednice $\mathrm{u}$ Hrvatskoj (Vedrana Baričević, Marina Matešić i Josip Šipić). Dubravka Mlinarić i Drago Župarić-Iljić u svom su radu predstavili probleme učenja jezika i uopće obrazovanje stranih maloljetnika bez pratnje u Hrvatskoj. Caroline Hornstein Tomić i Borna Pleše analizirali su međunarodnu mobilnost hrvatskih IKT stručnjaka usmjerujući se na razumijevanje izazovâ i složenosti migracija visokokvalificiranih pojedinaca.

Radovi u drugoj sesiji mogu se obuhvatiti temom Etničnost $i$ fertilitet. Aleksandar Knežević u svom se radu bavio metodološkim problemima $u$ etnodemografskim istraživanjima flotantnih etničkih skupina. U okviru te sesije bile su zastupljene i teme poput promjena u sastavu stanovništva prema narodnosti u pojedinim hrvatskim županijama u posljednjih dvadeset godina (Ivo Turk, Nikola Šimunić i Marta Jovanić) te suvremenih trendova fertiliteta narodnosnih skupina u
Hrvatskoj (Dario Pavić). Jelena Stojilković Gnjatović približila je sudionicima konferencije promjene u nacionalnoj strukturi starijeg stanovništva Srbije između dva popisa, a Natalija Mirić i Mirjana Devedžić fertilitet u romskim naseljima u Srbiji. Izložen je i rad o depopulaciji ruralnih prostora u Bosni i Hercegovini na primjeru općina Bugojno i Konjic (Alma Pobrić i Nusret Drešković).

Tržište rada, razvoj i migracije naziv je treće sesije, koja je okupila pet radova. Robert Skenderović govorio je o povezanosti migracija i održivoga iskorištavanja prirodnih resursa na primjeru krčenja šuma pri naseljavanju Slavonije. Aktualna tema nezaposlenosti bila je zastupljena $\mathrm{u}$ radu Roka Mišetića i Damira Miloša, koji su analizirali migracije i nezaposlenost mladog i zrelog stanovništva u Hrvatskoj, te u radu Valerije Botrić, koja je analizirala nezaposlenost doseljenih u Hrvatsku. Upravljanje migracijama u svrhu razvoja razmatrali su na primjeru Šumadije i Pomoravlja Gordana Vojković, Vera Gligorijević i Vlasta Kokotović, dok su Anđelko Akrap, Ivan Čipin i Petra Međimurec na primjeru Hrvatske analizirali očekivane selidbe tijekom životnog ciklusa.

U okviru četvrte sesije pod nazivom Imigracijski procesi $i$ identitet Marijeta Rajković Iveta analizirala je imigraciju hrvatskog iseljeništva iz Venezuele i Argentine u Hrvatsku i/ili EU, dok su se Katica Jurčević, Rebeka Mesarić Žabčić i Magdalena Vrbanec bavile percepcijom povratka $\mathrm{u} \mathrm{Hr}$ vatsku. Marijana Bičvić analizirala je konstrukciju identiteta mladih migranata iz Slavonije u Njemačkoj, a Dragana Radojičić dovela je u vezu migracije i kulturu prehrane u 21. sto- 
ljeću. Ulogu arhivske građe u istraživanjima migracija na primjeru Vukovarsko-srijemske županije istražili su Dražen Živić i Petar Elez.

Peta sesija Multietničnost $i$ identitet sastojala se od pet radova. Raspravljalo se o etničkim identitetima u južnoj Panoniji i Dalmaciji u Justinijanovo doba (Hrvoje Gračanin i Jana Škrgulja), regionalnim identitetima na primjeru Vojvodine (Ksenija Perković) te identitetu zadarskih Arbanasa (Dragutin Babić i Šenol Selimović). U okviru te sesije prezentirani su i rad Jelene Šesnić o etničkome i transnacionalnome hrvatsko-američkom pismu te rad Jerneja Zupančiča o koncepciji integracije romskih naselja u Sloveniji.

Posljednje dvije sesije sastojale su se od po šest izlaganja. Sesija Unutrašnje migracije: uzroci $i$ posljedice bila je većinom usmjerena na unutrašnje migracije u Republici Srbiji, analizirajući prostornu distribuciju migrantskog stanovništva u Srbiji na početku 21. stoljeća (Danica Šantić), općenito migracije stanovništva na prostoru Republike Srbije (Milka Bubalo-Živković, Tamara Lukić i Bojan Đerčan), a posebno unutrašnje migracije prema sjeveru (Vladimir Nikitović). Usto su se preko motiva za doseljavanje analizirali stambena mobilnost u Beogradu (Jovana Todorić, Ivan Ratkaj i Marija Ivković) te demografski profili malih gradova u Srbiji (Vlasta Kokotović i Marija Drobnjaković). Iako se izdvaja po lokaciji, tematski vezan uz unutrašnje migracije bio je i rad Marija Bare, Sonje Podgorelec i Sanje Klempić Bogadi, koji su sudionicima približili migraciju životnih stilova na hrvatskim otocima.
U posljednjoj sesiji Nacionalne manjine: status i prava u usporednom su manjinskom kontekstu prikazani Slovenci u Hrvatskoj i Hrvati u Sloveniji (Vera Kržišnik-Bukić), analizirana su kolektivna prava manjina u Sloveniji (Dejan Valentinčič) i etnička prijelaznost i neprijelaznost slovensko-hrvatske granice (Damir Josipović). Također su predstavljeni demografski podaci o doseljavanju Albanaca u Hrvatsku u posljednjih šezdeset godina (Nenad Pokosi i Zlatko Hasanbegović). Nešto apstraktnijim pristupom Tomislav Janović analizirao je kolektivne interese i njihovu zaštitu iz perspektive "malih" zajednica, dok su Aleksandar Vukić, Marina Perić Kaselj i Filip Škiljan na slučaju bivše Jugoslavije razmatrali povezanost liberalne političke misli i konstrukcije manjinsko-većinske etničke situacije.

Izuzetno velik odaziv sudionika i drugih uzvanika konferencije govori o aktualnosti tema kojima se časopis sustavno bavi već trideset godina, što se u hrvatskim uvjetima otežanog financiranja i zanemarivanja uloge znanosti u društvu može smatrati velikim uspjehom. $S$ druge strane, primjer ove konferencije upozorava na potrebu šre rasprave o zastupljenim temama kako na prostoru Hrvatske tako i u susjednim zemljama s obzirom na to da su se na ovoj jednodnevnoj konferenciji otvorila mnoga pitanja, ali i mogućnosti za sklapanje novih suradnji pomoću kojih bi ona mogla dobiti odgovore.

\section{Margareta Gregurović}

Institut za migracije i narodnosti, Zagreb 